\title{
GENDER INFLUENCE FOR TENSES OF GRAMMAR UNDERSTANDING IN ENGLISH STUDENTS 2018-A OF STKIP PGRI JOMBANG
}

\author{
Nala Sita Rukmi \\ English Department 2016-B Of STKIP PGRI Jombang \\ nallarukminingsih16@gmail.com \\ Nada Fakhril Imami \\ English Department 2016-B Of STKIP PGRI Jombang \\ nallarukminingsih16@gmail.com \\ Chalimah,M.Pd \\ English Department 2016-B Of STKIP PGRI Jombang \\ chalimahstkipjb@gmail.com
}

\begin{abstract}
Tenses in grammar are considered to be one of the difficult parts of learning English by most young students, because tenses are not well mastered by students as a simple indicator, general students think twelve or maybe sixteen tenses in English. This conceptual confusion leads to a low budget for applying English in the right limits. According to Merriam Webster gender is a person's internal sense of being male, female, some combination of male and female, or neither male nor female. Female and male have different characteristics and different abilities as in understanding grammar. According to Grey (2001) convey that female have the verbal intelligence (language) than male.The type of the research was analytic observational with Microsoft Excel.The study was conducted in English students 2017-B of STKIP PGRI JOMBANG. The population in this study was English students 2017-B of STKIP PGRI JOMBANG. The sample in this study was 10 students that consist 5 male students and 5 female students. The research instrument to collect data was a questioners. The results showed that Gender influences the results of students' understanding of grammar. The factor that most influences the results is the level of student learning. Female is more diligent than male, evidenced by female learning English every day, while male learns English only every month.
\end{abstract}

Keyword: grammar understanding, gender. 


\section{INTRODUCTION}

In the current era of globalization the mastery of a foreign language is very important especially English as an international language. In the education of modern college students required to be able to master English with correct grammatical. Tenses in grammar are a set of rules that explores the forms and structures of sentences that can be used in a language (Gleason and Ratner, 2009: 231-269; Thornbury, 1999). This conceptual confusion leads to low performance to apply tense of English under the right circumstances, there are still many difficulties in grammatical. Mastery of English grammar is very important because if the grammatical is wrong then the meaning conveyed will be different.

According to Merriam Webster gender is a person's internal sense of being male, female, some combination of male and female, or neither male nor female. Female and male have different characteristics and different abilities as in understanding grammar. According to Grey (2001) convey that female have the verbal intelligence (language) than male. Some people assume that gender is very influential in understanding something. Female are considered more perceptive in understanding a thing while the male are more sluggish in understanding a thing.So, we do the research to prove the assumption that gender affects society's understanding of grammar.

\section{Research question}

1. If there is a difference in student learning outcomes for male and female students 2017-B English Students of STKIP PGRI JOMBANG?

2. If there are factors that cause a difference in student learning results of male and female students 2017- B English Students of STKIP PGRI JOMBANG?

\section{METHOD}

The type of the research was analytic observational with Microsoft Excel.The study was conducted in English students 2017-B of STKIP PGRI JOMBANG. The population in this study was English students 2017-B of STKIP PGRI JOMBANG. The sample in this study was 10 students that consist 5 male students and 5 female students. The research instrument to collect data was a questioners. 
RESULTS AND DISCUSSION

\begin{tabular}{llll}
\hline Name & S1 & S2 & S3 \\
\hline Zumrotus S & $\mathbf{2}$ & $\mathbf{2}$ & $\mathbf{3}$ \\
\hline $\begin{array}{l}\text { Cholidah } \\
\text { Irfan }\end{array}$ & $\mathbf{3}$ & $\mathbf{3}$ & $\mathbf{2}$ \\
$\begin{array}{l}\text { Sabilla nur } \\
\text { farisa }\end{array}$ & $\mathbf{3}$ & $\mathbf{3}$ & $\mathbf{2}$ \\
\hline Findy mia & $\mathbf{2}$ & $\mathbf{3}$ & $\mathbf{3}$ \\
\hline Oki duwi & $\mathbf{2}$ & $\mathbf{2}$ & $\mathbf{3}$ \\
\hline Mean & $\mathbf{1 2}$ & $\mathbf{1 3}$ & $\mathbf{1 3}$ \\
\hline & & & \\
\hline Riza alfian & $\mathbf{1}$ & $\mathbf{2}$ & $\mathbf{2}$ \\
\hline Fajar el fikri & $\mathbf{2}$ & $\mathbf{1}$ & $\mathbf{2}$ \\
\hline M. Dimas & $\mathbf{2}$ & $\mathbf{1}$ & $\mathbf{1}$ \\
\hline Rizky Dwi & $\mathbf{1}$ & $\mathbf{3}$ & $\mathbf{1}$ \\
\hline M. Haril & $\mathbf{1}$ & $\mathbf{1}$ & $\mathbf{2}$ \\
\hline Mean & $\mathbf{1 2}$ & $\mathbf{8}$ & $\mathbf{1 3}$ \\
\hline
\end{tabular}

\section{NOTE:}

$3=$ More Understand

$2=$ Understand

$1=$ Didn`t Understand

Based on the table 1 shows that the male agrees if they like English while the female does not like English. Male and female understand well about how to apply the tense used in short stories. Female know that short stories used simple past. Male prefer that short stories used present continuous .Male and female know that tenses of Grammar is very interesting. They also strongly agree that Grammar is very difficult. Whereas male tend to learn and practice by doing the task of English every month and female learn and practice by doing the task of English every day. Male and female often do group work to solve a problem together. The average male and female have attended English courses.

\begin{tabular}{lc}
\hline NAME & SCORE \\
\hline Cholidah Irfan & 8 \\
\hline Sabilla nur farisa & 8 \\
\hline Findy mia & 8 \\
\hline Oki duwi & 8 \\
\hline Zumrotus sholikah & 7 \\
\hline MEAN & 8 \\
\hline Riza alfian & 5 \\
\hline Fajar el fikri & 5 \\
\hline M. Dimas & 4 \\
\hline Rizky Dwi & 5 \\
\hline M. Haril & 4 \\
\hline MEAN & 5 \\
\hline
\end{tabular}

Based on table 2 shows that there are differences in the value of the grammar test between male and female. Female gets the highest average score compared to male.

\section{CONCLUSION}

From the results of the research we conducted, it can be concluded that Gender influences the results of students' understanding tenses of grammar. The factor that most influences the results is the level of student learning. Female is more diligent than male, evidenced by female learning English every day, while male learns English only every month. 
Rukmi dan Imami, Gender Influence...

\section{REFERENCES}

Gender identity, Merriam Webster, accessed on https://www.merriamwebster.com/dictionary/gender\%20i dentityJanuary, 082019 at 12.10 PM

Pengaruh gender dalam berbahasa dan bermasyarakat, Solikhah Hani accessed on http://www.academia.edu/11936512 /Pengaruh_Gender_dalam_Berbahas a dan BermasyarakatJanuary, 07 2019 at 15.05 PM 